\title{
PENGARUH MENONTON VCD TENTANG CIDERA KEPALA TERHADAP KEPATUHAN MENGGUNAKAN HELM SISWA SMK PENGENDARA SEPEDA MOTOR DI KOTA SURAKARTA
}

\author{
Suyanto ${ }^{1}$, Hartono ${ }^{2}$ \\ Poltekkes Kemenkes Surakarta Jurusan Keperawatan
}

\begin{abstract}
Background: Various efforts have been made to reduce the risk of head injury due to motorcycle accident. But the effort has not succeeded that looks still high head injury rate so that it enters in 10 diseases most in Surakarta. Police records, motorcycle accidents in the Surakarta region ranks the highest compared to five other Central Java areas which tend to increase. An effort to reduce the risk of head injury is to increase knowledge about head injury. Especially in the vocational school students who use motorcycles for their groups at high risk of accidents and head injuries. The study wanted to see the effect of watching videos on knowledge and compliance using helmets of motorcycling students in Surakarta. Method: The design of this study was quasi experiment using pre-post test approach on population of vocational students in Surakarta with 343 samples using a knowledge questionnaire observation and compliance observation sheets using a helmet. Research data were analyzed using Chi Square Test. Result: The results showed that there was a significant difference in knowledge of vocational students about head injuries before and after watching video. As for the helmet there are significant differences. Conclusion: Researchers suggest student knowledge about head injury and compliance using a helmet.
\end{abstract}

Keywords: Video, Helmet, Compliance, Head injury

\section{PENDAHULUAN}

Semakin meningkatnya angka kejadian cidera kepala akibat kecelakaan pada para pengendara sepeda motor memerlukan perhatian dan penanganan yang komprehensif. Oleh karena itu hingga saat ini berbagai upaya telah dilakukan oleh pihak terkait seperti menerapkan peraturan penggunaan jenis helm yang memenuhi Standar Nasional Indonesia (SNI) dan kampanye safety riding . Tetapi upaya tersebut belum membuahkan hasil yang maksimal ditandai oleh tetap tingginya kejadian cidera kepala pada para pengendara sepeda motor.
Organisasi Kesehatan Dunia (2014) menyatakan bahwa cidera kepala parah dapat menyebabkan kematian dan kecacatan. Untuk itu pengendara sepeda motor perlu diingatkan tentang faktor risiko cidera kepala yang dapat menyebabkan kerusakan otak permanen. Apalagi ketika melihat jumlah biaya yang harus dikeluarkan untuk operasi, pembelian obat-obatan dan biaya perawatan. Lebih lanjut, dinyatakan bahwa satu-satunya cara efektif untuk mengurangi angka kematian akibat cidera kepala pada pengendara sepeda motor adalah dengan menggunakan helm yang dapat mengurangi risiko dan keparahan dari cedera sekitar $72 \%$, mengurangi 
kemungkinan kematian akibat cedera sampai 39\% (Antou, Siwu, \& Mallo, 2013). Namun hingga saat ini semua upaya untuk meningkatkan kepatuhan pengendara sepeda motor yang telah dilakukan belum mendapatkan hasil yang maksimal. Jadi bisa dipahami jika angka kecelakaan cukup tinggi seperti di wilayah Kota Surakarta polisi cenderung meningkat. Hal tersebut terlihat pada catatan jumlah cidera kepala di ruang gawat darurat RSUD Dr.Moewardi Surakarta yang menangani sebagian besar cidera kepala disebabkan oleh kecelakaan lalu lintas. Di tingkat nasional, insiden cidera kepala menduduki peringkat 3 dari 10 penyakit paling umum di beberapa rumah sakit di Indonesia.

Selama ini penggunaan helm oleh pengendara sepeda motor dianggap sebagai bentuk kepatuhan terhadap aturan dan hukum yang berlaku yaitu UU No. 22 tahun 2009 tentang Lalu Lintas dan Angkutan Jalan. Pendekatan ini mendukung pendekatan yuridis dengan memberikan sanksi hukum kepada pengendara yang melanggar peraturan lalu lintas. Untuk mengubahnya dapat menggunakan pendekatan pendidikan kesehatan yang belum banyak dikembangkan. Beberapa kegiatan telah dilakukan seperti kampanye keselamatan berkendara dan kampanye pengguna helm tetapi belum memenuhi kepatuhan menggunakan helm yang lebih baik. Diharapkan bahwa melalui pendekatan pendidikan kesehatan, pengendara akan menyadari ancaman terhadap kesehatan mereka dalam bentuk cidera kepala.

Salah satu metode untuk mengubah persepsi dan kepatuhan yaitu menggunakan video sebagai alat telah dijelaskan oleh Bastle (2003). Berubahnya persepsi diharapkan dapat mengubah perilaku seperti kepatuhan terhadap saran dari petugas kesehatan.

Hasil penelitian (Tondok. at all, 2012) mencatat bahwa selama ini helm hanya digunakan saat bepergian jauh, atau ketika ada polisi atau ketika diingat. Juga terungkap bahwa kepatuhan mereka terhadap helm tidak dilakukan dengan sepenuh hati karena hanya mematuhi aturan atau hukum yang berlaku. Untuk itu peneliti tertarik menyelesaikan penelitian yang ada sehingga dapat mengungkapkan apakah pemahaman tentang dampak cidera kepala melalui pendidikan kesehatan menggunakan media video dapat meningkatkan kepatuhan penggunaan helm?

Penelitian ini dilakukan pada siswa kejuruan yang memiliki karakteristik siswa yang berbeda dengan sekolah menengah yang telah diteliti oleh dan Puri (2014). Perilaku siswa kejuruan memiliki rasa kebebasan dan cenderung agresif, terutama pada waktu berangkat dan pulang sekolah dengan menggunakan sepeda motor.




para siswa SMK pengendara sepeda motor di kota Surakarta sebelum dan sesudah diberi pendidikan kesehatan.

Hasil penelitian ini diharapkan dapat diketahui peningkatan pengetahuan siswa Sekolah Kejuruan secara keseluruhan tentang cidera kepala dan kepatuhan menggunakan helm kepatuhan.

\section{METODE PENELITIAN}

Penelitian ini menggunakan desain quasi-eksperimen pretest-posttest pada populasi penelitian siswa SMK di kota Surakarta. Pengambilan sampel dilakukan sebanyak 25\% dari 54 SMK sehingga jumlah sampel diperoleh sebanyak 12 SMK. Jumlah populasi sebanyak 4997 siswa pada 12 SMK tersebut diambil sampel secara acak. Berdasarkan tabel Krecjie diperoleh sampel sebanyak 370 orang dan ditentukan pengambilannya dengan teknik purposive karena sampel penelitian ini adalah siswa yang mengendarai sepeda motor saat pergi ke sekolah. Pada saat penelitian ada satu sekolah dengan jumlah sampel 27 siswa mengundurkan diri sehingga jumlah sampel menjadi 343 orang.

Data dikumpulkan pada bulan Agustus dan September 2017 dengan mengukur pengetahuan responden menggunakan kuesioner tentang cidera kepala sebelum dan sesudah menonton video yang dikembangkan dari Manual Keselamatan Jalan Untuk Pengambil Keputusan dan Praktisi (WHO, 2014). Data kepatuhan menggunakan helm diukur menggunakan lembar observasi untuk mengamati siswa sebelum menonton video dan setelah menonton video berisi film tentang cidera kepala akibat kecelakaan sepeda motor yang tidak menggunakan helm dan operasi otak (kraniotomi).

Secara terperinci urutan penentuan dan pengumpulan data responden penelitian ini yaitu: Responden adalah siswa SMK yang mengendarai sepeda motor ke sekolah. Selanjutnya menentukan siswa yang akan menjadi responden secara acak baik kelas maupun jenis kelaminnya sesuai dengan jumlah sampel. Siswa yang terpilih menjadi responden dicatat dan dilakukan pengamatan terhadap responden meliputi pemakaian helm, jenis helm standar SNI dan pengikatan tali helm selama 3 (tiga) hari pengamatan. Responden diberikan lembar informed consent dan kuesioner pretes. Setelah selesai mengisi kuesioner diberikan VCD untuk ditonton dirumah dan 3 (tiga) hari kemudian responden diamati lagi selama 3 (tiga) hari meliputi pemakaian helm, jenis helm standar SNI dan pengikatan tali helm. Terakhir responden diberikan kuesioner postest.

Analisis data dilakukan untuk melihat perbedaan variabel pengetahuan dan kepatuhan sebelum dan sesudah perlakuan berupa menonton video dengan menggunakan uji kuadrat (Chi square).

\section{HASIL PENELITIAN}

\section{Hasil Analisa Univariat}

Karakteristik responden berdasarkan usia dapat dilihat pada tabel 1 berikut ini.

Tabel 1. Karakteristik Responden

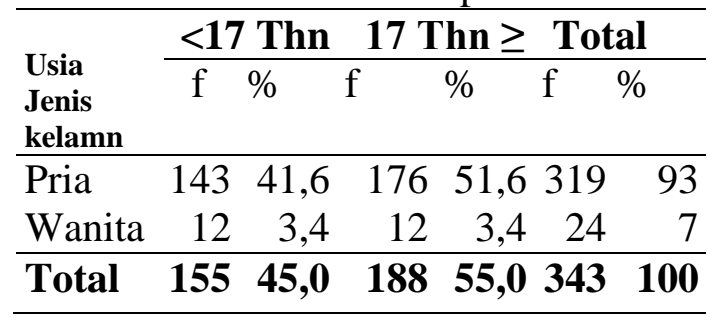

Berdasarkan tabel 1 terlihat bahwa sebagian besar sebanyak 319 responden 
(93\%) berjenis kelamin pria dan sisanya 7\% atau 24 responden berjenis kelamin wanita. Sedangkan utuk usia responden yang kurang dari 17 tahun sebesar $45 \%$ (155 orang) dan yang berusia diatas 17 tahun sebanyak $55 \%$ (188 orang).

Tabel 2. Tingkat Pengetahuan Responden sebelum menonton VCD

\begin{tabular}{lcc}
\hline Pengetahuan & Jumlah & Persentase \\
\hline Baik & 339 & 98,8 \\
Sedang & 2 & 0,6 \\
Buruk & 2 & 0,6 \\
\hline Jumlah & $\mathbf{3 4 3}$ & $\mathbf{1 0 0}$ \\
\hline
\end{tabular}

Berdasarkan tabel 2 terlihat bahwa tingkat pengetahuan responden sebelum menonton VCD sebagian besar $(98,8 \%)$ baik sedangkan yang berkategori sedang dan buruk masing masing hanya 2 orang atau $0,6 \%$.

Tabel 3. Hasil Observasi Kepatuhan menggunakan Helm Sebelum menonton VCD

\begin{tabular}{lcc}
\hline Hasil Observasi & f & \% \\
\hline Patuh & 175 & 51 \\
Tidak patuh & 168 & 49 \\
\hline Jumlah & $\mathbf{3 4 3}$ & $\mathbf{1 0 0}$ \\
\hline
\end{tabular}

Berdasarkan tabel 3 dapat dilihat bahwa dari 343 orang responden yang menjadi sampel dalam penelitian ini berdasarkan observasi sebelum menonton VCD terdapat 168 responden (49\%) tidak patuh menggunakan helm saat mengendarai sepeda motor sedang sebagian besar lainnya yaitu 175 (51\%) patuh menggunakan helm.

Tabel 4. Tingkat Pengetahuan Responden sesudah menonton VCD

\begin{tabular}{lrr}
\hline Pengetahuan & Jumlah & Persentase \\
\hline Baik & 342 & 99,7 \\
Sedang & 1 & 0,3
\end{tabular}

\begin{tabular}{lrr} 
Buruk & 0 & 0 \\
\hline Jumlah & $\mathbf{3 4 3}$ & $\mathbf{1 0 0}$ \\
\hline
\end{tabular}

Selanjutnya berdasarkan tabel 4 terlihat bahwa sesudah menonton VCD tentang akibat cidera kepala hampir semuanya $(99,7 \%)$ berpengetahuan baik hanya 1 orang responden yang memiliki pengetahuan sedang.

Tabel 5. Hasil Observasi Kepatuhan Menggunakan Helm Sesudah menonton VCD

\begin{tabular}{lcc}
\hline Hasil Observasi & f & \% \\
\hline Patuh & 300 & 87,5 \\
Tidak patuh & 43 & 12,5 \\
\hline Jumlah & $\mathbf{3 4 3}$ & $\mathbf{1 0 0}$ \\
\hline
\end{tabular}

Terlihat pada tabel 5 bahwa dari 343 orang responden yang menjadi sampel dalam penelitian ini berdasarkan observasi sesudah menonton VCD terdapat 300 responden $(87,5 \%)$ patuh menggunakan helm saat mengendarai sepeda motor dan masih dijumpai responden yang tidak patuh yaitu sebanyak 43 orang $(12,5 \%)$.

\section{Hasil Analisa Bivariat}

Tabel 6. Perbedaan pengetahuan responden sebelum dan sesudah menonton VCD

\begin{tabular}{|c|c|c|c|c|c|c|c|}
\hline \multirow{3}{*}{$\begin{array}{l}\text { Pengetahuan } \\
\text { Sebelum } \\
\text { menonton } \\
\text { VCD } \\
\end{array}$} & \multicolumn{4}{|c|}{$\begin{array}{c}\text { Sesudah menonton } \\
\text { VCD }\end{array}$} & \multirow{2}{*}{\multicolumn{2}{|c|}{ Total }} & \multirow[t]{3}{*}{$\begin{array}{l}\text { p. } \\
\text { value }\end{array}$} \\
\hline & \multicolumn{2}{|c|}{ Baik } & \multicolumn{2}{|c|}{ sedang } & & & \\
\hline & $\mathbf{n}$ & $\%$ & $\mathbf{n}$ & $\%$ & $\mathbf{n}$ & $\%$ & \\
\hline Baik & 338 & 99 & 1 & 0,3 & 339 & 99 & 0,994 \\
\hline Sedang & 2 & 0,5 & 0 & 0 & 2 & 0,5 & \\
\hline Buruk & 2 & 0,5 & 0 & 0 & 2 & 0,5 & \\
\hline Jumlah & 342 & 99,7 & 1 & $\mathbf{0 , 3}$ & 343 & 100 & \\
\hline
\end{tabular}

Berdasarkan tabel 6 terlihat bahwa pengetahuan responden tentang cidera kepala akibat mengendarai sepeda motor tidak menggunakan helm sebelum dan sesudah menonton VCD memiliki nilai $p$ value $0,994>0,05$. Dengan demikian 
berarti tidak terdapat perbedaan pengetahuan antara sebelum dan sesudah menonton VCD.

Tabel 7. Kepatuhan responden sebelum dan sesudah menonton VCD

\begin{tabular}{|c|c|c|c|c|c|c|c|}
\hline \multirow{3}{*}{$\begin{array}{l}\text { Kepatuhan } \\
\text { Sebelum } \\
\text { menonton } \\
\text { VCD }\end{array}$} & \multicolumn{4}{|c|}{$\begin{array}{c}\text { Sesudah menonton } \\
\text { VCD }\end{array}$} & \multirow{2}{*}{\multicolumn{2}{|c|}{ Total }} & \multirow[t]{3}{*}{$\begin{array}{c}\text { p. } \\
\text { value }\end{array}$} \\
\hline & \multicolumn{2}{|c|}{$\begin{array}{l}\text { Tidak } \\
\text { patuh }\end{array}$} & \multicolumn{2}{|c|}{ patuh } & & & \\
\hline & $\mathrm{n}$ & $\%$ & $\mathrm{n}$ & $\%$ & $\mathrm{n}$ & $\%$ & \\
\hline Tidak & 42 & 25 & 126 & 75 & 168 & 49 & 0,000 \\
\hline Patuh & & & & & & & \\
\hline Patuh & 1 & 0,6 & 174 & 99,4 & 175 & 51 & \\
\hline Jumlah & 43 & 12,5 & 300 & 87,5 & 343 & 100 & \\
\hline
\end{tabular}

Berdasarkan tabel 7 terlihat bahwa kepatuhan menggunakan helm saat mengendarai sepeda motor para siswa SMK di Kota Surakarta sebelum dan sesudah menonton VCD memiliki nilai $\mathrm{p}$ value $0,00<0,05$. Dengan demikian berarti terdapat perbedaan yang signifikan kepatuhan antara sebelum dan sesudah menonton VCD.

\section{PEMBAHASAN}

Kejadian cidera kepala paling banyak adalah akibat kecelakaan lalu lintas para pengendara sepeda motor karena tidak digunakannya helm pengaman, serta didukung oleh tidak mematuhi peraturan lalu lintas dan tidak dilengkapinya kendaraan dengan peralatan sebagaimana mestinya seperti lampu stop dan sign yang menyala dan kaca spion.

Untuk itu para pengendara sepeda motor perlu diingatkan terhadap faktor resiko yang yang akan ditanggung seperti cidera kepala yang dapat menyebabkan kerusakan otak secara permanen. Terlebih lagi bila melihat besarnya biaya yang harus dikeluarkan untuk operasi, pembelian obat dan biaya perawatan.
Berikut akan disajikan pembahasan hasil penelitiannya.

\section{Pengetahuan responden tentang cidera kepala}

Berdasarkan hasil pengumpulan data menggunakan kuesioner yang dilakukan sebelum dan sesudah menonton video dan dilanjutkan dengan menganalisanya diperoleh hasil bahwa tingkat pengetahuan responden adalah baik. Sebelum menonton video hampir semua responden $(98,9) \quad$ yaitu 339 berpengetahuan baik dan hanya 2 orang yang berpengetahuan sedang dan 2 orang berpengetahuan buruk. Sedangkan tingkat pengetahuan sesudah menonton video terjadi peningkatan yaitu tidak terdapat responden yang berpengetahuan buruk dan hanya 1 orang yang berpengetahuan sedang serta tidak ditemukan yang berpengetahuan buruk.

Hasil penelitian ini berbeda dengan penelitian yang dilakukan oleh (Chrussiawanti, 2015) tentang hubungan antara pengetahuan dan kepatuhan safety riding pada remaja di SMAN 2 Sukoharjo Jawa Tengah. Berdasarkan penelitian tersebut diperoleh hasil bahwa sebagian besar $63,4 \%$ berpengatahuan cukup dan yang baik hanya $19,7 \%$. Terlebih bila dibandingkan dengan hasil penelitian yang dilakukan lain (Suyanto, 2014) yang mendapatkan bahwa persepsi responden siswa SMA di Bandar Lampung terhadap penyakit cidera kepala sebelum diberikan pendidikan kesehatan sebagaian besar berkategori tidak baik sebanyak $56 \%$ dan berkategori buruk sebanyak $44 \%$.

Perbedaan hasil penelitian tersebut dapat difahami bahwa saat ini informasi tentang cidera kepala disebabkan tidak menggunakan helm saat mengendarai sepeda motor sudah banyak diunggah dan mudah diakses melalui internet dan 
media sosial dalam berbagai bentuk seperti video yang dilakukan oleh Kepolisian RI maupun oleh orang pribadi.

Sebagaimana diketahui bahwa sepeda motor pada awalnya diciptakan bukan moda transportasi, melainkan sebagai alat delivery atau sport. Sehingga faktor keselamatan sebagai moda trasportasi sejak awal pembuatan tidak disiapkan. Untuk itu beberapa faktor resiko yang akan terjadi karena kecelakaan sepeda motor harus diketahui oleh pengendara seperti cidera kepala dimana korban kecelakaan dapat mengalami cidera kepala bahkan mengalami kerusakan otak secara permanen. Kemudian biaya ekonomi yang dikeluarkan untuk biaya pengobatan seperti operasi, pembelian obat dan biaya perawatan yang sanggat besar.

Upaya pencegahan cidera kepala dari aspek penggunaan helm dapat dilakukan dengan cara memenuhi semua syarat saat menggunakannya. Penggunaan helm yang memenuhi standard dan digunakan dengan benar adalah salah satu cara pencegahan cidera kepala.

Selanjutnya berdasarkan hasil analisa perbedaan pengetahuan tentang cidera kepala antara sebelum dan sudah menonton video diperoleh hasil $\mathrm{p}$ value $0,994>0,05$. Dengan demikian hipotesa Null yaitu tidak terdapat perbedaan pengetahuan tentang akibat cidera kepala antara sebelum dan sesudah menonton VCD para siswa SMK pengendara sepeda motor di Surakarta diterima.

Diterimanya hipotesis Null yaitu tidak terdapat perbedaan pengetahuan tentang akibat cidera kepala antara sebelum dan sesudah menonton VCD para siswa SMK di Kota Surakarta dapat difahami mengingat bahwa berbagai pihak seperti Kepolisian RI telah mengadakan penyuluhan tentang peraturan hukum dan Undang Undang khususnya Undang Undang Lalu Lintas tentang penggunaan helm bagi para pengendara sepeda motor. Tidak terlepas kemungkinan bahwa dalam penjelasan hukum penggunaan helm tersebut juga disinggung tenntang akibat yang akan dialami bagi pengendara sepeda motor yang tidak menggunakannya.

\section{Kepatuhan menggunakan helm \\ responden}

Hasil pengumpulan data kepatuhan responden menggunakan helm menggunakan lembar observasi yang dilakukan sebelum dan sesudah menonton video dan dilanjutkan dengan menganalisanya diperoleh hasil sebagai berikut.

Kepatuhan responden sebelum menonton video hampir sama yaitu $51 \%$ ( 175 responden) patuh dan 49\% (168 responden) tidak patuh. Sedangkan sesudah menonton video terjadi peningkatan dimana $87,5 \% \quad(300$ reponden) patuh dan masih terdapat responden yang tidak patuh sebanyak $12,5 \%$ (34 responden).

Berdasarkan hasil analisa univariat kepatuhan responden dalam meggunakan helm terlihat adanya peningkatan kepatuhan antara sebelum dan sesudah menonton VCD meskipun masih terdapat 34 responden $(12,5 \%)$ yang belum patuh. Hal tersebut dapat dijelaskan sebagaimana pendapat Bastle (2003) yang menyatakan bahwa kepatuhan memiliki kecendrungan manipulatif dan otoriter sehingga petugas dianggap sebagai tokoh yang berwenang dan klien atau masyarakat harus patuh. Namun demikian berbeda dalam bidang kesehatan karena setiap individu memilki 
hak untuk membuat keputusan akan patuh atau tidak patuh mengikuti anjuran yang disampaikan petugas kesehatan. Sehingga dapat dikatakan bahwa kepatuhan berbanding lurus dengan tujuan yang akan dicapai yang sangat memerlukan motivasi dari petugas.

Selanjutnya berdasarkan hasil analisa perbedaan kepatuhan menggunakan helm antara sebelum dan sudah menonton video diperoleh hasil $\mathrm{p}$ value $0,00<0,05$. Dengan demikian hipotesa Null yaitu tidak terdapat perbedaan kepatuhan menggunakan helm antara sebelum dan sesudah menonton VCD para siswa SMK pengendara sepeda motor di Surakarta ditolak.

Berdasarkan analisa penelitian ini menunjukkan kesesuaian dengan teori bahwa kepatuhan seseorang dalam menggunakan helm dapat dipengatruhi oleh berbagai hal. Sebagaimana dijelaskan Eraker dkk dan Laventhal dan Cameron (Bastle, 2003) mengatakan bahwa kepatuhan dalam bidang kesehatan dapat ditinjau dari bidang perspektif biomedis yang menyangkut keseriusan penyakit dan kompleksitas pengobatan. Selain itu juga dijelaskan dalam teori keyakinan rasional yang menimbang manfaat pengobatan dan resiko penyakit melalui penggunaan logika cost benefit.

Dalam video yang telah ditonton oleh responden telah digambarkan tentang keseriusan penyakit yang disebabkan ketidak patuhan menggunakan helm saat mengendarai sepeda motor, kompleksitas pengobatan yang harus dilakukan, resiko dan komplikasi jika dilakukan operasi dan besarnya biaya yang harus ditanggung.
Setelah menonton video kepatuhan responden menjadi meningkat dimungkinkan karena melihat keseriusan dan kompleksitas pengobatan serta besarnya biaya yang harus ditanggung jika mengalami cidera kepala.

Kepatuhan responden yang meningkat setelah dilakukan pendekatan pendidikan kesehatan menggunakan Health Belief Model (Bastle, 2003). Berdasarkan model dapat diprediksi perilaku kesehatan yang akan terjadi jika tiga komponen utama berinteraksi. Tiga komponen utama tersebut yang pertama adalah persepsi individu terhadap ancaman penyakit yaitu cidera kepala. Komponen kedua yaitu faktor pengubah/ pemodifikasi yang akan mempengaruhi persepsi individu terhadap sebuah penyakit yaitu cidera kepala. Ketiga yaitu faktor tindakan yang dapat dilakukan oleh seseorang terhadap ancaman sebuah penyakit yaitu cidera kepala. Seseorang dapat bertindak patuh atau tidak patuh menggunakan helm saat mengendarai sepeda motor.

Oleh karena itu responden harus memiliki persepsi atau pengetahuan yang baik tentang sebuah penyakit yaitu cidera kepala dengan cara diberikan pendidikan kesehatan menggunakan media VCD. Sebagaimana beberapa hasil penelitian menunjukkan bahwa penyuluhan kesehatan menggunakan metode ceramah disertai pemutaran VCD secara signifikan memberikan dampak positif yang lebih nyata dibandingkan metode ceramah tanpa VCD terhadap pengetahuan (Sitepu, 2008) sehingga muncul tindakan terhadap ancaman cidera kepala tersebut berupa kepatuhan menggunakan helm. 


\section{KESIMPULAN DAN SARAN}

Kesimpulan:

Berdasarkan hasil penelitian dan analisa serta pembahasannya maka dapat diambil beberapa kesimpulan. Pertama yaitu bahwa tidak terdapat perbedaan pengetahuan tentang akibat cidera kepala antara sebelum dan sesudah menonton VCD para siswa SMK pengendara sepeda motor di Surakarta. Kedua terdapat perbedaan kepatuhan menggunakan helm antara sebelum dan sesudah menonton VCD para siswa SMK pengendara sepeda motor di Kota Surakarta

Saran:

Guna menghindari kejadian cidera kepala pada siswa yang mengendarai sepeda motor saat berangkat ke sekolah kiranya perlu dilakukan peningkatan pengetahuan responden tentang cidera kepala khususnya bagi siswa baru disekolah tersebut. Program yang dapat dikembangkan yaitu pendidikan kesehatan mengggunakan media VCD berisi keseriusan dan kompleksitas pengobatan serta besarnya biaya yang harus ditanggung jika mengalami cidera kepala. Bagi peneliti lain disarankan untuk melanjutkan penelitian ini dengan jumlah sampel yang lebih banyak dan metode yang lebih baik lagi serta mempertimbangkan variabel lainnya.

\section{DAFTAR RUJUKAN}

Antou, S. W., Siwu, J. F., \& Mallo, J. F. (2013). Manfaat Helm Dalam mencegah kematian Akibat Cedera Kepala Pada Kecelakaan Lalu Lintas. Jurnal Biomedik. Retrieved from https://ejournal.unsrat.ac.id/index. php/biomedik/article/viewFile/260 $\underline{3 / 2146}$
Bastle, S. B. (2003). Nurse as Educator: Principles of Teaching and Learning for Nursing Practice. Clinical Nurse Specialist. https://doi.org/10.3274/JL10-69$\underline{1-06}$

Chrussiawanti. (2015). HUBUNGAN Tingkatpengetahuandengan Kepatuhan Safety Ridingpada Remaja Di Sma Negeri 2 Sukoharjo. Retrieved from http://digilib.stikeskusumahusada. ac.id/download.php?id=1593

Sitepu. (2008). Efektivitas Penyuluhan Kesehatan Menggunakan Metode Ceramah Disertai Pemutaran VCD Dan Tanpa Pemutaran VCD Dalam Meningkatkan Pengetahuan Dan Sikap Ibu Tentang Penyakit Pneumonia Pada Balita Di Kecamatan Stabat Kabupaten Langkat. Retrieved from http://repository.usu.ac.id/handle/ $\underline{123456789 / 6725}$

Suyanto, anita puri. (2014). efek pendidikan kesehatan terhadap persepsi tentang cidera kepla dan kepatuhan menggunakan helm siswa SMA pengendara sepeda motor di bandar lampung. Jurnal Kesehatan Holistik, 6, 7-11. Retrieved from http://ejurnal.malahayati.ac.id/ind ex.php?journal=hlstk\&page $=$ articl e\&op=view\&path\%5B \%5D=613

Tondok. at all. (2012). Intensi kepatuhan menggunakan helm pada pengendara sepeda motor: aplikasi teori perilaku terencana. Retrieved from http://repository.ubaya.ac.id/3466/ 1/Marselius_Intensi kepatuhan_R2.pdf 
WHO. (2014). Helm Manual keselamatan jalan untuk pengambil keputusan dan praktisi. Retrieved from http://apps.who.int/iris/bitstream/1 0665/43261/52/9241562994_ind.p df 